\title{
2021 年度産業応用部門役員会・委員会名簿
}

\section{役 員 会}

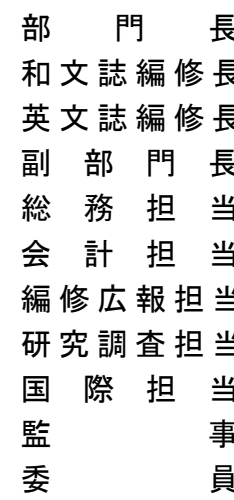

委 員 長 榎本 裕治（日立製作所）

副 委 員 長 鳥羽 章夫 (富士電機) 藤本 康孝（横浜国立大学）

幹

委

事 名取 賢二 (千葉大学) 葛巻 淳彦 (東芝インフラシステムズ)

員 関 健太（名古屋工業大学）嶋田 尊衛（日立製作所）早坂 高雅（鉄道総合技術研究所）

宮崎 敏昌（長岡技術科学大学）伊藤 和晃（岐阜大学）藤崎 敬介（豊田工業大学）

小坂 卓 (名古屋工業大学) 桂 誠一郎（慶應義塾大学）伊東 淳一（長岡技術科学大学）

下野 誠通 (横浜国立大学) 内村 裕 (芝浦工業大学) 大山 和宏 (福岡工業大学) 千葉 明 (東京工業大学) 森下 明平 (工学院大学) 山際 昭雄 (ダイキン工業) 貝塚 正明 (本田技術研究所) 細野 裕行（日本大学） 古関 隆章 (東京大学) 久保田 直行 (東京都立大学) 三橋 郁 (職業能力開発総合大学校)

福山 良和 (明治大学) 井上 潔（東京下水道エネルギー）高木 喜久雄（東芝エネルギーシステムズ）

\section{国 際 委 員 会}

委員
副委員
幹
委

$\begin{array}{cccc}\text { 委 } & \text { 員 } & \text { 長 } \\ \text { 副 } & \text { 委 } & \text { 員 } & \text { 長 } \\ \text { 幹 } & & \text { 事 } \\ \text { 委 } & & & \text { 員 }\end{array}$

赤津 観（横浜国立大学）

長 近藤 圭一郎 (早稲田大学)

事 横山 智紀 (東京電機大学) 名取 賢二 (千葉大学) 桂 誠一郎（慶應義塾大学）

員 伊東 淳一 (長岡技術科学大学) 大石 潔 (長岡技術科学大学) 大橋 俊介 (関西大学)

黒川 不二雄（長崎総合科学大学）佐藤 宣夫（千葉工業大学）清水 敏久（東京都立大学）

玉井 伸三 (東芝三菱電機産業システム) 西田 保幸 (千葉工業大学) 野口 季彦 (静岡大学)

藤本 博志 (東京大学) 藤本 康孝 (横浜国立大学) 星 伸一 (東京理科大学)

村上 俊之（慶應義塾大学）和田 圭二（東京都立大学）

\section{編修広報委員会}

岩路 善尚（茨城大学）

塚越 昌彦 (東芝三菱電機産業システム) 藤本 博志 (東京大学)

事 小南 勉 (日立製作所) 井上 征則 (大阪府立大学)

員 山田 親稔 (沖縄工業高等専門学校) 鳥羽 章夫 (富士電機) 葛巻 淳彦（東芝インフラシステムズ）

森本 進也 (安川電機) 熱海 武憲 (千葉工業大学) 真木 康次（東芝インフラシステムズ）

國分 博之 (富士電機) 藪井 将太 (東京都市大学) 加藤 雅之 (茨木大学)

小山 昌人 (三重大学) 猪又 健太朗 (安川電機) 篠原 篤志 (鹿児島大学)

高橋 健治 (三菱電機) 五十嵐 大介（日立製作所）川口 悟（成蹊大学）

浮田 啓悟（鉄道総合技術研究所）萬年 智介（筑波大学）中村 雅史（東芝三菱電機産業システム）

村松 久圭 (広島大学) 馬飼野 祐貴（日立製作所）萩尾 悠樹（東芝三菱電機産業システム）

藤井 淳 (デンソー) 齋藤 亮介（東芝インフラシステムズ）平塚 大佑（ダイキン工業）

星 靖之 (明電舎) 山之内 亘（沼津工業高専）麻原 寛之（岡山理科大学）梅谷 和弘 (岡山大学)

草野 大輔 (安川電機) 野龒 正浩（東洋電機製造）野下 裕市（九州大学） 